\title{
高分子イオンの構造形成
}

\author{
伊 勢 典 夫 \\ 京都大学工学部高分子化学教室 $\mathbf{T} 606$ 京都市左京区吉田本町
}

\section{Structure Formation in Dilute Solutions of Ionic Species}

\section{Norio IsE}

Kyoto University, Yoshida Honmachi, Sakyo-ku, Kyoto 606

The current status of the experimental and theoretical study on ionic solutions is reviewed. The small-angle X-ray scattering (SAXS) curves on ionic solutes such as proteins, polynucleotides, synthetic macroions, surfactant micelles and so on, show a single, broad peak, which suggests intermolecular ordering of the macroions in solutions caused by an electrostatic attractive interaction These information is confirmed by investigation on a model system, namely on polymer latex particles, which can be studied by naked eyes with an optical microscope. The micrographs provide a visible evidence for the interparticle attraction. The distortion of the ordered structure is fairly large and is a reason of the non-existence of higher order peaks in SAXS curves. The nature of the attraction, which clearly shows the invalidity of the DLVO theory on colloidal stability., is discussed in terms of a recent theory.

Key words: Ordering, Macroions, Latex particles, Small-angle X-ray scattering,

Paracrystalline distortion

ご紹介いただきました伊勢ででざいます．膜学会は私 あ会員を務めさせていただいておりますが，昨今やって おります事が余り膜に関係でざいませんものですから, ついつい疎縁になっておるというのが実情でございま す.それで, 最初に「話をしろ」とおっしゃった時に, どうも私の話は皆さんの技役に立ちそうにないので一応 固辞したつもりだったのですが，いつの間にかプログラ ムがまいりまして「講演をしろ」という話です. 恐らく 何にも扮役にたたないのではないかと思うのですが， あ う少し濃厚になりまして膜になってまいりますと, 大い に膜の機能とは関係があるだろうと兼々思っている溶液 の話をさせていただてうと思います。いずれ濃厚系に入 りまして膜の問題にまで近づきたいとは思うのですが, まだ稀薄溶液の段階でなかなか問題がふっきれないもの ですから，いつまでも足を引っ張られているような感じ ででざいます。それで題にもございましたように，いろ いろなイオン性の高分子ですが, これが溶液の中で, 特
に薄い溶液の中で並ぶというのがポイントででざいま す.われわれが最近得ていますデータを中心にしてお話 を申上げたいと思います。

Fig. 1 はプラスチックのボールであります, 同じ大き さのものをたくさん作りまして, 一定の箱の中に入れま す。そうすると, 非常に濃厚な溶液に対応するわけです が, 大きさと形がそろっておりますと, いや応なしにき

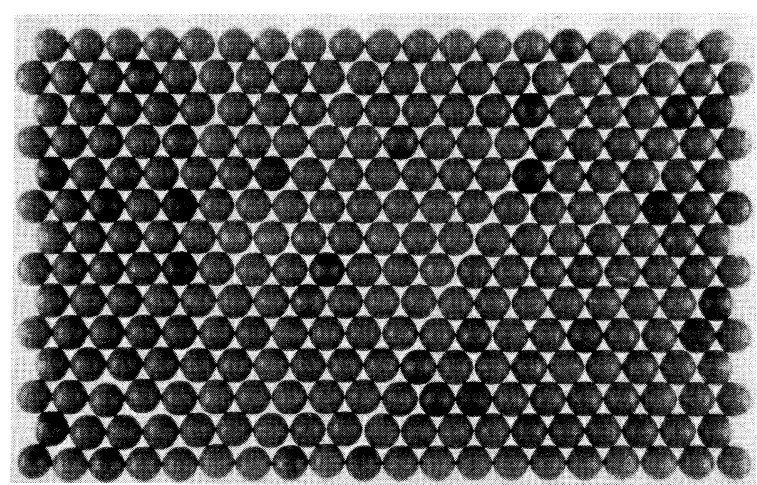

Fig. 1 
れいに並ぶわけです．問題はこれがあっとあっと薄くな った時にどうなるかということです．だんだん薄くなり ますと, 我々が期待しますのは, 粒子がいろいろな方向 にブラウン運動しているということであるわけです．と ころが，乙の溶液をある条件にあっていきますと，粒子 が規則正しく並びだすわけです，それについては，何か 特別な理由がある，あるいは，何か特別な力が働かなけ ればいけないわけですが，それを調べるというのが現在 の私達の仕事の目的であるわけです。

それで結論を先に申上げますと，高分子イオンであろ うが，ビールス粒子であろうが, 高分子のラテックスで あろうが，タンパクであろうが，また核酸であろうが， あちろん酵素もそうでありますが，荷電を持っているい ろいろな溶質を非常に薄い溶液にいたしましてある条件 を与えますと, Fig. 2のように局部的に集まりまして, しかあかなりきれいな配列を示すというのが結論ででざ います，決して溶液中全体に広がっているのではありま せんで，てういうローカライズした規則性がでてくると いうのが結論であります.

まず最初に目に見えない方ですが, 目に見えないので 話はどうしてもまず信じて見て頂くということになりま す．後でまたての逆を申上げます．とにかく今から 40 年位前にアラビン酸というイオン性の高分子であります が，その溶液つ光散乱をVeisらが調査しまして, 電荷数 をどんどん上げていきますと, $K c / R_{90}$ の值が大きくな

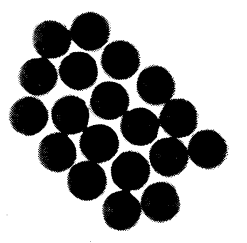

Fig. 2

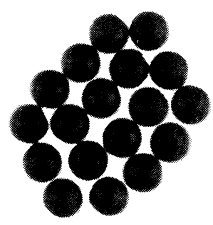

るということを見つけたわけです (Fig. 3). Dotyや Fuoss らも同様の実験を行い, 電荷が与えられると溶液 が濁らなくなることに気付いたわけです。つまり溶液の 中を光が素通しになるわけです. Doty屯Fuoss む何か お互い高分子の間にインターフェアレンスがあって，そ れが何かのノンランダムネスを引き起てしているという ふうに説明をしているわけです。これにはいろいろな疑 問があるわけですが，アインシュタイン流にいいますと， 光散乱というのは濃度のゆらぎで起こるわけで, きれい に並びますとゆらぎが落ちますから， $K c / R_{90}$ が上がって

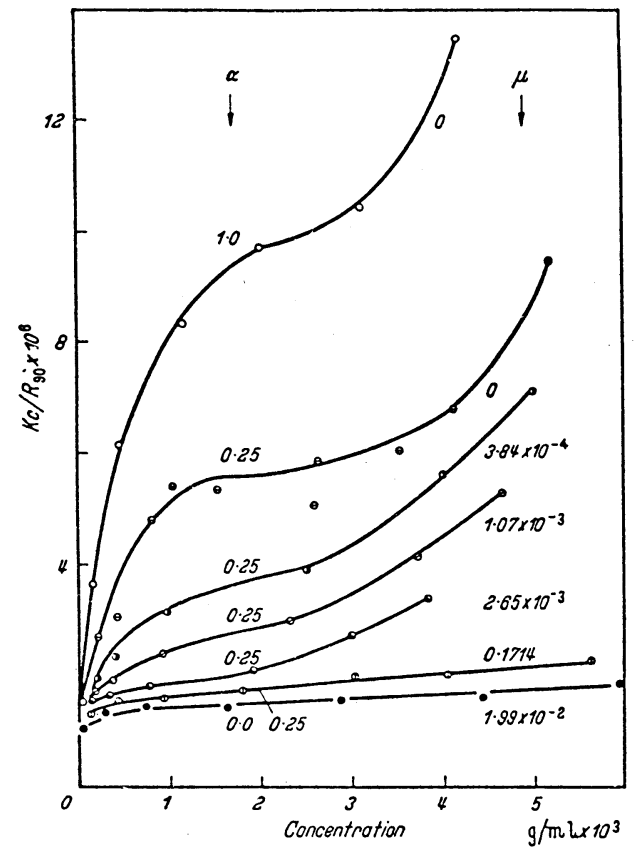

Fig. 3 A. Veiss, D. N. Eggenberger: J. Amer. Chem. Soc., 76, 1560 (1954)

くるという，非常に定性的な説明ででざいます。乙れか らしばらくしまして, 私共も熱力学的な測定をいたしま して,やはりどうしてあ高分子イオンが並んでいると考 えた方が説明がつきやすいという事情を見つけたわけで す.

1979 年に鋭敏な X 線散乱装置ができ上り，高分子の 教室に入りました。当時の河合弘廸先生に打願いしまし て，ポリアクリル酸ソーダを非常に系統的に調べたわけ です. Fig. 4 は最近のデータで, ポリスチレンスルホン 酸という高分子であります。

縦軸が散乱強度で, 横軸が Braggの角度であります が, 曲線に必ずピークが 1 つでてくるわけです，濃度が 高くなるに従っててのピークが広角側に移るという現象 が観察されます。なお，私共はX線の専門家でないもの ですから，ての実験に使いました試料を，チェコの高分 子研究所のDusekに送って同じ実験条件で測定して あらったわけです．乙の人はほとんど我々と同じころに 同じようにピークを見つけたのです．その結果が曲線 3 プライムです。ことピーク位置に関しましては両方の間 に非常にきれいな一致ができたわけです。そういう歴史 的ないわくがでざいます。とにかくピークは 1 つです.

Fig. 5 が添加塩をほり込んだらどうなるかということ を示しています。非常にきれいな水を使いますとこうい 


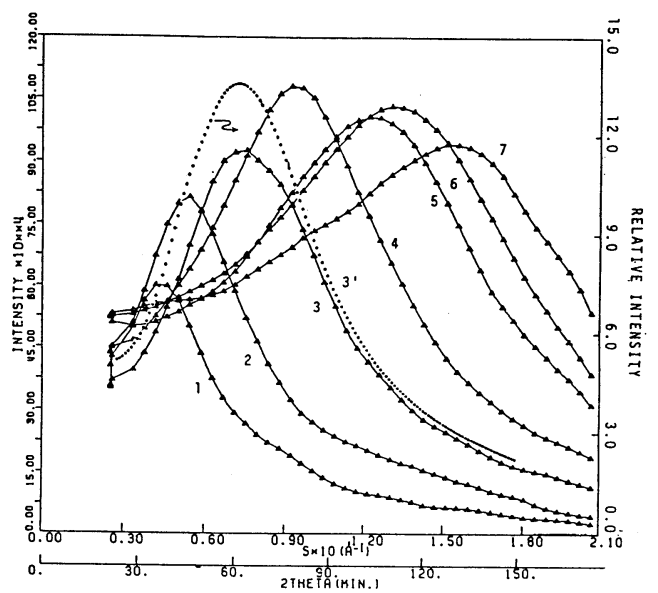

Fig. 4 N. Ise, et al.: J. Chem. Phys., 81, 3294 (1984)

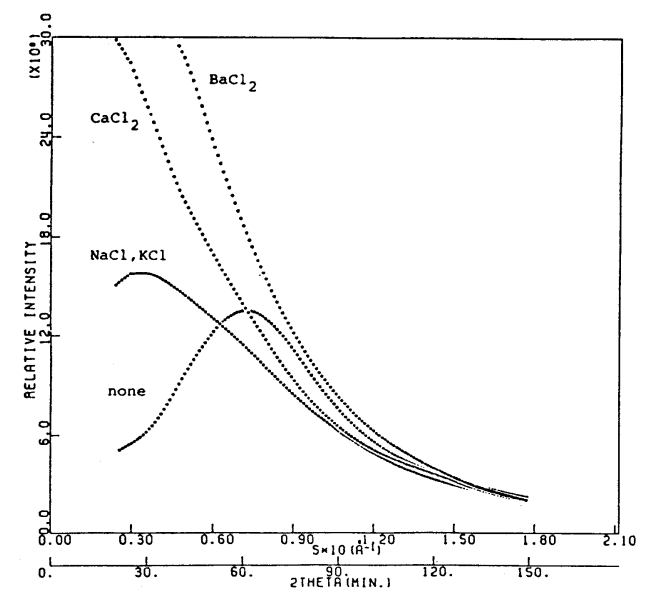

Fig. 5 N. Ise, et al.: J. Chem. Phys., 81, 3294 (1984)

うピークができます。それに $\mathrm{NaCl}, \mathrm{KCl}$ というふうな 第 3 の塩を加えていきますと, 乙のピークは低角側にシ フトします. シフトして最後には全部なくなって, 単調 な減少関数になります。このようなととは, ピークを作 り上げているとてろの何かの規則性が静電的な力に由来 するということを意味するわけです。

それから，その次に合成高分子の特徴を利用いたしま して，今度はそのピークが何かということを調べるわけ です. Fig. 6 はポリスチレンスルホン酸についての最近 の実験データですが，で存知のように，乙の試料は非常 に狭い分子量分布を持ちます。 $M_{W} / M_{N}$ の比がだいたい 1.17 ぐらいなります.乙れほよ゙シャーブな分子量分布な あのですから，標準サンプルに都合が良いわけです。そ れで, 分子量が違う2つのサンプルを調べたわけです。
膜 (MEMBRANE)，Vol.11 No.4 (1986)

219

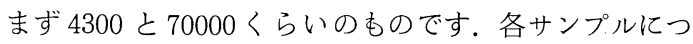
いて独立の測定をやりました。明らかにピーク位置は分 子量に依存しました，その次にこの 2 つを等量混ぜまし て 2 成分系を作るわけです，それでX線解析をやってみ ますと, オブザーブされた実験がカーブ 3 であります. カーブ 4 と書いてありますのは, カーブ 1 と 2 とを単純 に加算いたしまして, 濃度を補正して得られる合成曲線 であります。ちょっと肩のようなのがでますが,てれは 結局低分子量成分のピークに対応しているわけです。む ちろん, 今の場合二つのピークが接近していますのでて ういうカーブになりますが, あしかなり離れていました ら必ず二つのピークをあつ曲線になるはずです，ところ が実際に実験いたしますと必ず真中に 1 つピークを持つ 曲線がでてくる. 結局, 乙の事は, 仮りに, 例えば, 分 子内へリックスをまいておりますと，その長さがピークに 反映することもあるわけですが, 各成分のピークが仮り にそういう規則性からでてくるとしたら，てれらを混ぜ た場合に，2つのピークが観測されて当り前です．とて ろが, 実際にでてくるのはそうはなりませんで必ず真ん 中に 1 つのピークです.ですから分子内の規則性ではな くて必ず分子間のものに違いないと思われるわけです. 勿論, 他のタンパクその他ではこういう実験ができませ んで，分子量分布があるという合成高分子の 1 つの特性 を逆用したわけです．高分子イオンがどういう形をとっ ているかというのはこれまた相当な議論になりますが, 一応系まり状になっておりますと, Fig. 7 のように溶液 中で比較的きれいに並んでいると結論できるわけです.

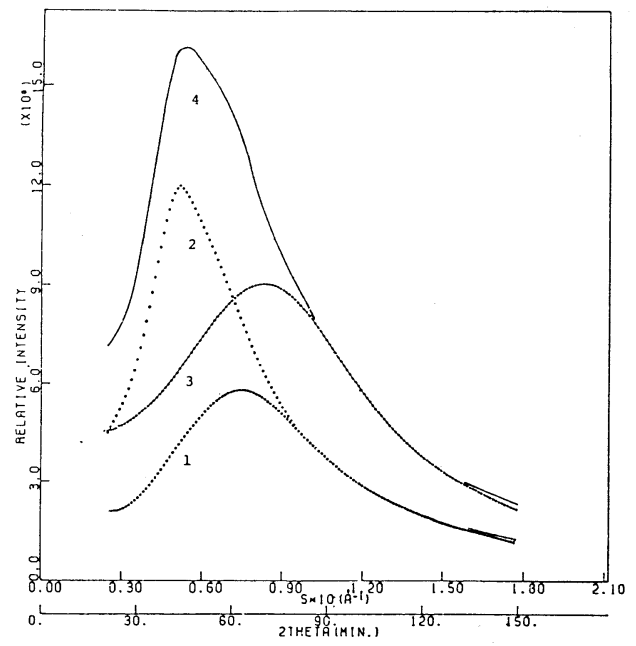

Fig. 6 N. Ise, et al.: J. Chem. Phys., 81, 3294 (1984) 
こういうオーダーリングがX線のピークとして現われて いるのではなかろうかと結論しているわけです。むして の仮説を許していただけるといたしますと, 分子間の距 離を $2 D_{\exp }$ といたしますと, あとは教養で習う物理の話 でありまして, 結局, Braggの式

$$
n \lambda=2\left(2 D_{\exp }\right) \cdot \sin \theta
$$

で, $\lambda$ は波長, $n$ は次数, それから $\theta$ は実測でわかるわ けですから，当然算術ででてくるわけであります。ての 距離をだしてみますと, 非常に面白いことがわかります (Fig. 8). 試料は poly-L-lysine, プラスの電荷を持つ 高分子と, ポリアクリル酸であります。横軸は $\mathrm{NaCl}$ の 濃度をとっているわけです。そうしますと， $2 D_{\exp }$ はて ういう変化をいたします，濃度を上げていくに従って距 離は大きくなります。あう1つ見ていただきたいのは, $2 D_{0}$ という值です. 今高分子の重量がわかって, 分子 量がわかっていますから, 結局その溶液の中にある数が わかるわけです．数がわかりますので，てれらの高分子 が溶液の中で一様に分布していると仮定しますと，分子 間の平均距離がでてまいります。乙れが $2 D_{0}$ であります。 この平均距離は明らかに Bragg 距離よりも2 倍くらい 大きいようです。ですから，溶液の中でてういう合成高 分子は決して一様にきれいに並んでいるのではないと期 待されるわけであります. どうも Fig. 2 のように, ロー カルに並んでいるというふうに考えざるをえないわけで す.

それから, Fig 9はごく最近のデータですが, 牛の血 清アルブミンであります。乙れは,プラス, マイナスの 両方の電荷を持っているわけです，X線解析を調べてみ ますと,まず $\mathrm{pH}=10$ にいたしますと, こういうピーク

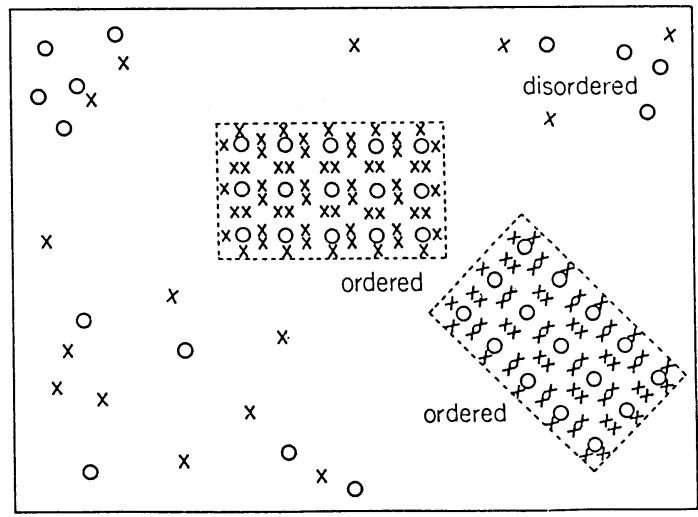

Fig. 7 N. Ise, T. Okubo: Acc. Chem. Res., 13, 303 (1980)
が 1 つでます. $\mathrm{pH}=3$ であやはり 1 つでます。とてろ が, 両方の電荷がちょうどバランスする点つまり等電点 にあっていきますと, てれが 5.06 , 正確な等電点は 4 . 8 です。そこにあっていくとピークは完全に消えてしま います。ですから，さき程の $\mathrm{NaCl} の$ 影響が示している のと全く同じでして, 要するに, このピークというのは

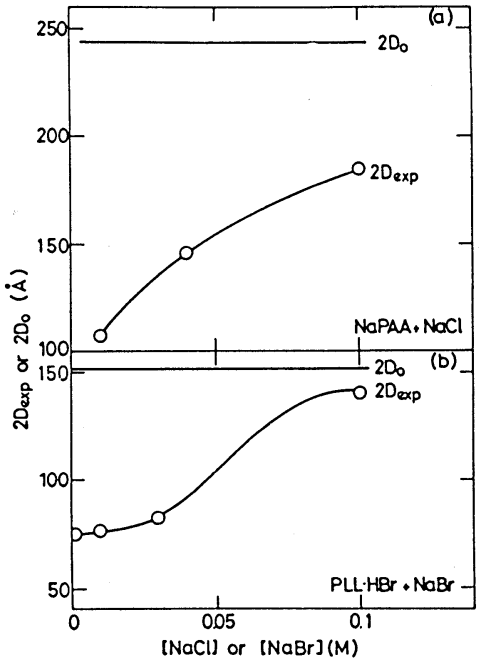

Fig. 8

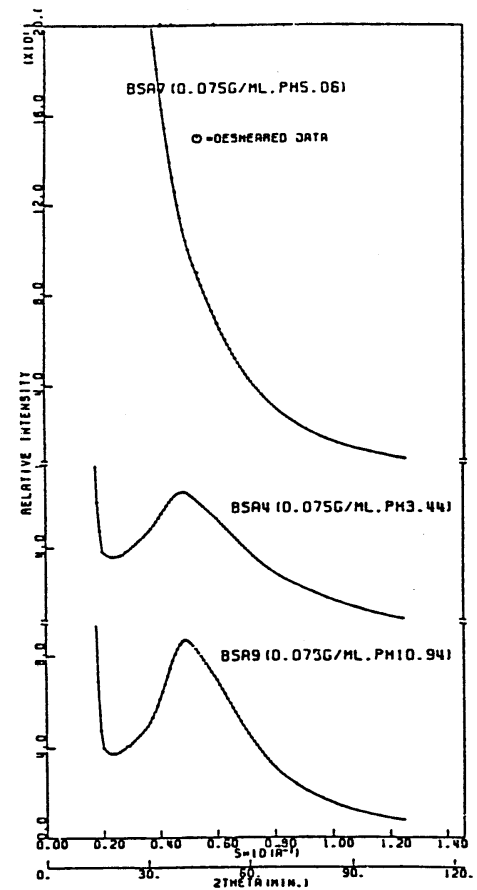

Fig. 9 H. Matsuoka, et al.: J. Chem., Phys., 83, 378 (1985) 
結局電気的は力の結果としてできているということにな るわけです.

それで, 今のBSAのタンパク質のデータから，ての タンパク質分子が打互いいくらくらい離机ているかとい うことを計算した結果を示します(Fig.10). 要するに, 電荷がプラスにしましてもマイナスにしましても, 電 荷数が増えると，必ず距離が隇少してきます．普通コ口 イド化学, あるいは高分子化学では, きれいに並んでい るということは受け入れられるわけですが, 粒子が電荷 を持っていますから，たがいに押し合い,へし合いして 並んでいるのだという理解が一般的であります。ところ があしそうだといたしますと, 電荷を増やして行ってあ 距離は増えないはずですから, 距離が小さくなる傾向と いうのは, その解釈に, 一つの?を执くことになるわけ です，後で申上げますが，とにかく高分子イオンの間に 引力が働いているとと, その引力が電荷数を上げるとと によって強くなるというふうに考えざるをえません．

それから、さきほどあ中性の場合にはピークがでない という括を申上げたのですが，同じてとがポリビニ ルピロリドン，乙れは代用血浆に使われている水溶性高 分子ですが，乙の時は完全にピークは出ていないわけで

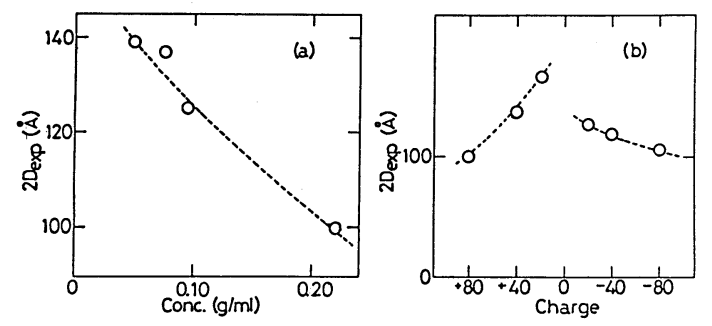

Fig.10

す.同じょうに電荷をむたないポリビニルアルコー ル，乙の場合にもやはりピークはでません．ピークは必 ず電荷をむった場合に限ります. Fig. 11 の曲線 2 とい うのはポリスチレンルスルホン酸ナトリウムで, 曲線 1 はポリビニルピロリドンです.てのポリビニルピロ リドンとポリスチレンスルホン酸を混ぜますとカーブ 4 になるわけです，ピーク位置は全然変わらないわけです． ポリビニルピロリドンという中性の高分子は, イオン 性高分子と全然違う領域に溶けているのか, あるいは才 ーダーリングをさまだけないような特殊な溶け方をして いるという推定になるわけです。

いろいろな試料があるのですが，つぎに挙げましたの は, 転移-RNA,乙れは, ご存知のマイナスの電荷をむつ

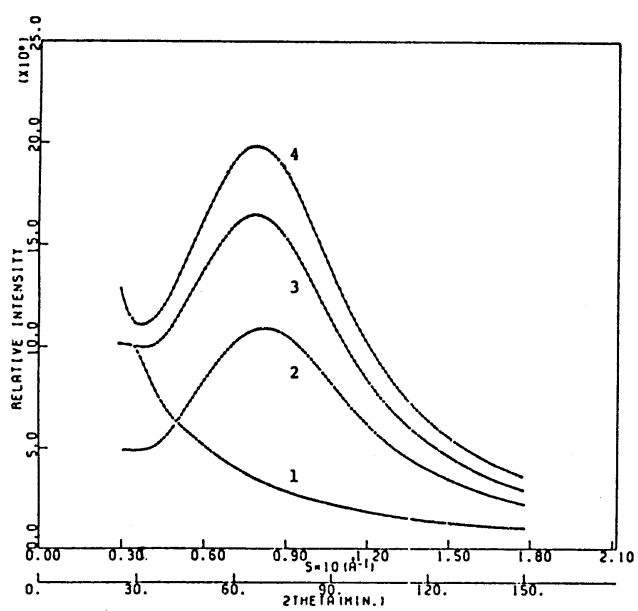

$$
\begin{aligned}
& \text { 1: PVP } 0.04 \mathrm{~g} / \mathrm{ml}, M W=50000 \text {. } \\
& \text { 2: NaPSS } 0.04 \mathrm{~g} / \mathrm{ml}, M W=74000 . \\
& \text { 3: NaPSS } 0.04 \mathrm{~g} / \mathrm{ml}+\text { PVP } 0.02 \mathrm{~g} / \mathrm{ml} \text {. } \\
& \text { 4: NaPSS } 0.04 \mathrm{~g} / \mathrm{ml}+\text { PVP } 0.04 \mathrm{~g} / \mathrm{ml} \text {. }
\end{aligned}
$$$$
\text { Scattering curves of NaPSS + PVP systems at } 25^{\circ} \mathrm{C} \text {. }
$$

Fig.11 N. Ise: J. Chem. Phys., 81, 3294(1984)

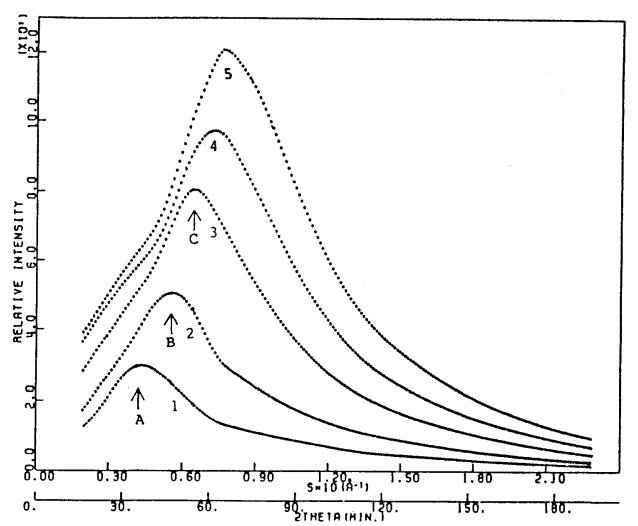

Fig.12 H. Matsuoka, et al.: J. Chem. Phys., 83, 378 (1985)

イオン性生体高分子, 乙れあやはりきれいにピークがみ られます.ただし, どう頑張ってみても2つ目がでてて ない，そうしますと，固体結晶を調べている人は,「てん なのは結晶と違う」という。「結晶だったら, Bragg の式に従いまして, $n$ の次数が変わってたくさんのピー クが必らずでてきてもいいはずだ」と.「打前の見てい るのはピーク1つだけだからてれは結晶じゃない」と， そういう反論がまずでてくるわけです．何故てういうふ うになるかというのはまた後で申上げます。

一応今までのデータ, その他を総合いたしまして, 溶 液の中でコロイド粒子とか, マイクロイオンというのは 


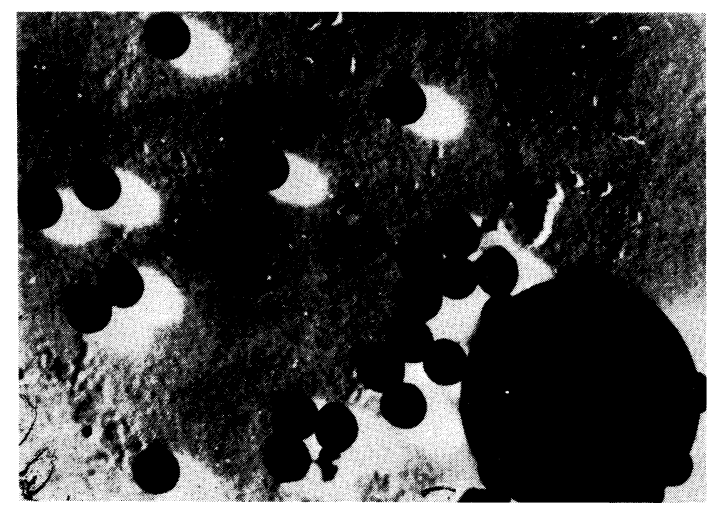

Fig. 13

均一に溶液をカバーして組織を作っているのではなく て, 局部的に比較的並んでいるとてろと, 全然disorder のとてろが共存していると考えた方が説明がつきやすい ということであります。そうすると，何故分子が互いに 引っ張られて寄ってきているかという, 単純な質問がで てくるわけです，答えはかなり難かしいわけでして，い ろいろな議論ができます.まず Braggの式を仮定するの が悪いとか, それから, 単一のピークを結晶と結びつけ るのはけしからんという話になります。ですから，一転 しましてもう少し大きいものを直接目でみて議論しては ということで, それでポリマーのラテックスを選ぶわけ です. で存知のように, 高分子ラテックスというのは今 の場合はスチレンですが，スチレンを水の中に分散させ てエマルジョンを作って, そのエマルジョンの大きさを 非常に注意深く調節する。そうしますと, 単分散性のラ テックスができるわけです. Fig. 13 は電子顕微鏡写真 ですが, これからいわゆる粒子の直径がわかり, 単分散

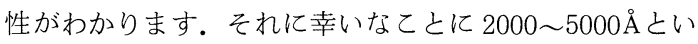
う直径のものを簡単に作ることができます。こういうあ のを水に分散させますと, 粒子が大きいですから光を乱 反射いたしまして，ちょうどミルク状に真白に濁るわけ です。濁った溶液を非常に注意深く透析にかけてやりま すとイリデセンスという発色現象がみられます。これは ラテックスを非常にきれいに精製した時にでてくる現象 です。初めて見つかったのは 30 年くらい前ですが，そ れからしばらくしまして, ドイッのBASFの物理学者 ですが，ルックという人が解明いたしました。それは， 結局ラテックスの粒子がきれいに溶液中に並びまして, てれによって可視光が回折されるためだというわけです. 可視光の中にはいろいろな波長のあのが入っていますの で, 各々の波長が違った $\theta$ で回折されるわけです.

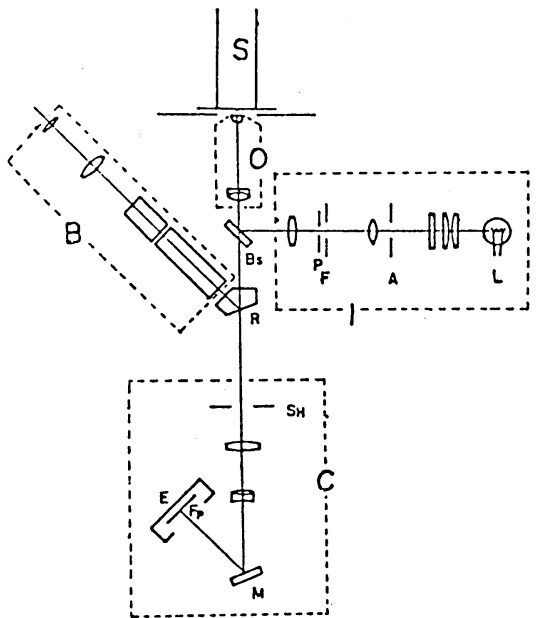

Fig.14 A. Kose, et al.: J. Coll., Interface Sci., 44, 330 (1973)

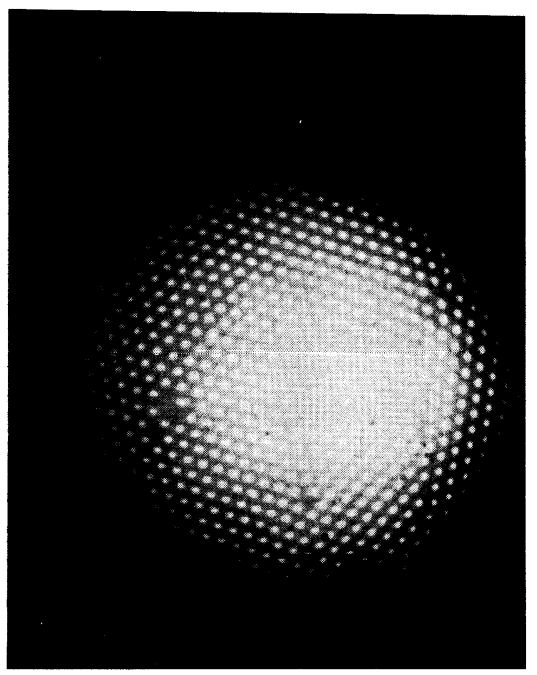

Fig.15

これで話はだいたい片づいたのですが，てれを更に確 実にして「目に物を見せた」のが蓮先生という東京教育 大の先生です。つまりラテックスの溶液を Fig. 14の S に置きまして，そして金属顕微鏡を使って粒子を見るて とに成功したわけです，Lに光源があって，光は $\mathrm{A}, \mathrm{P}$, Bsを通って $\mathrm{S}$ 亿り，Eで写真を撮るというテクニッ クであります。この技術を使わしていただいて撮った写 真の一つがFig. 15 であります.だいたい直径が $4000 \AA$ くらいのラテックスで, 濃度が $3 \%$ くいであります. 非常にきれいな六方晶形のパッキングをします．乙うい うふうに抢見せしますと, 皆さん電子顕微鏡写真だと思 われるのですが, あくまで光学顕微鏡写真です。この 


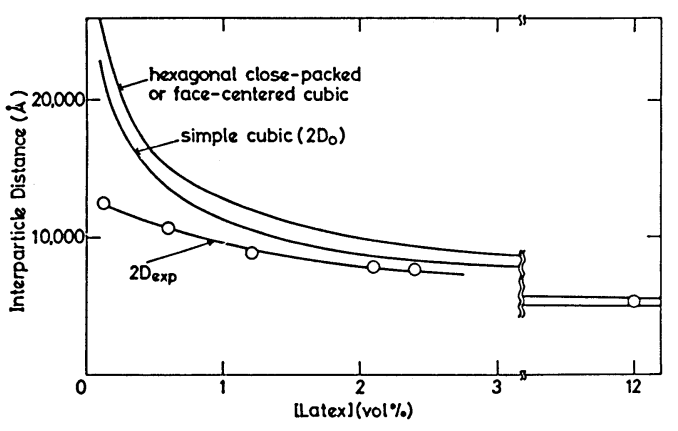

Center-to-Center Particle Distance in Ordered Region of $\mathrm{SO}_{3} \mathrm{H}$ Containing Latex Solutions Latex $=S S-23, \quad=3020 \AA, z=146 \times 10^{5}$

Fig.16 N. Ise, et al.: J. Chem. Phys., 78, 536 (1983)

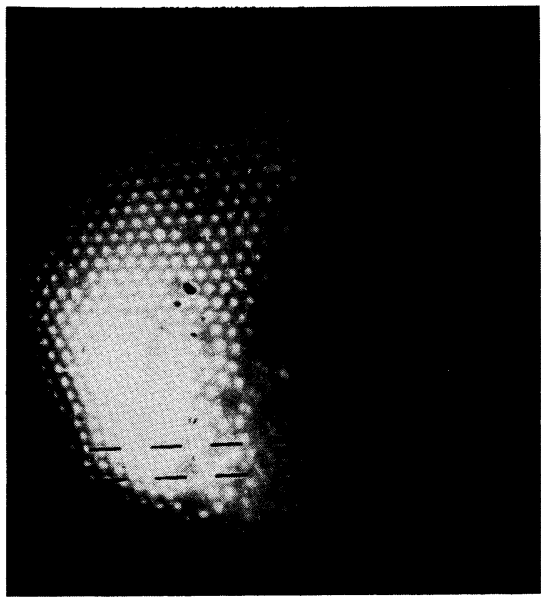

Fig.17

ような並んだ写真を撮っておきまして,粒子と粒子の 中心間距離を測定するわけです.そうすると, 結局 $2 D_{\text {exp }}$ というのがBraggの式を使わずにでてくる.もちろん, 収差その他は考えないといけませんが, とにかく何かの 理論を仮定する必要はないことは歷然であります。グラ フにいたしますと Fig. 16のようになります.

Fig. 16では, 0.15\%〜12\%まで濃度を変えているわ けです。一番下の曲線が奏々:マ、写真から読み取れた距離 であります。13000Åから $5000 \mathrm{~A}$ まで変わります。濃度 が高くなるとやはり小さくなります，粒子の大きさが わかって,比重がわかって抲ますから数がわかります。 てれから平均距離 $\left(2 D_{0}\right)$ がわかります. 非常に濃度が高 い $12 \%$ ところでは $5000 \AA$ で $2 D_{\exp }$ と $2 D_{0}$ はよく合 うわけです。 $0.15 \%$ で， $2 D_{\exp }$ が $1300 \AA$ で， $2 D_{0}$ が $2300 \AA$ 。明らかに $2 D_{0}$ が 2 倍位大きい.さっきのX線の 結果と完全にコンシステントになっているわけです。 そ
れから，あし実際にてういうふうに小さくなっている としますと, 当然ローカライズしたオーダリングを考え ないといけない。

Fig. 17 がその例です. この左半分はきれいに並んで るわけです，右の方にあ粒子があるのですが，乙れは自 由にブラウン運動いたしますので，ほとんどうつらない のです．それから 2 本線が図の下部にありますが，その 間隔は $10000 \AA$ であります. あとで 16 ミリで見ますが, 中央部分は完全にフリーな表面でして, 左側の粒子が蒸 発していって, 右側の蒸発しているのが凝固していくプ ロセスを見るととができます。とにかく溶液中のローカ ライズしたオーダリングを先程は Fig.3亿書いたわけで すが、それがラテックスを使いますと，実際に目に見え るということになります。そういうあのを説明するため には，どうしても粒子の間に引力の存在を仮定しないと いけない。むし析力だけでオーダリングしているのでし たら，てういうローカライズしたオーダリングというの はできるはずはありません，溶液中に広がってもっと 大きな距離できれいに並ぶということが起てるはずです。 それでは一体何が引力を引き起てしているかというこ とですが Fig. 18 をでらん下さい. よく考えてみますと 我々の周囲によく似た事例に沢山あります。例えば三重 イオンとイオン対と自由イオンです。マイナスープラス ーマイナスというペアーを考えます。距離 $r$ はなれてい て電荷が $-e,+e,-e$ とします.そうすると三重イオン のポテンシャルエネルギーというのは，まずー $(e)^{2} / r$ 乙 れは引力です. 第 2 項むやはり引力です. 第 3 項はマ イナスーマイナスですから，てれは当然反撥ですが，そ の距離が $2 r$ になりまして $r$ より大きくなります．て れを全部足し算してやると, 結局 $2 r$ という距離が大き いむのですからー $(3 / 2) \cdot(e)^{2} / r$ になる。とてろが，む し仮りにイオンの 1 つが解離しまして無限大にいってイ オン対だけ残ったという場合だけを考えますと，ポテ

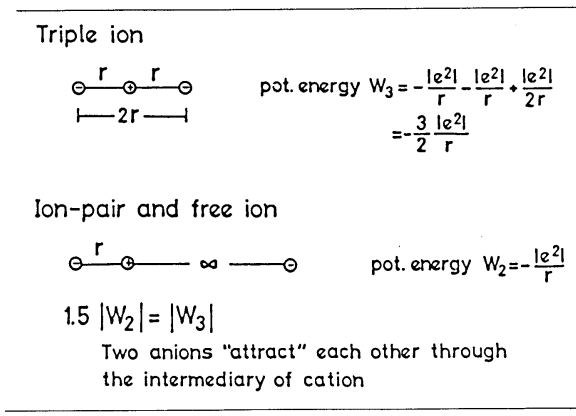

Fig.18 


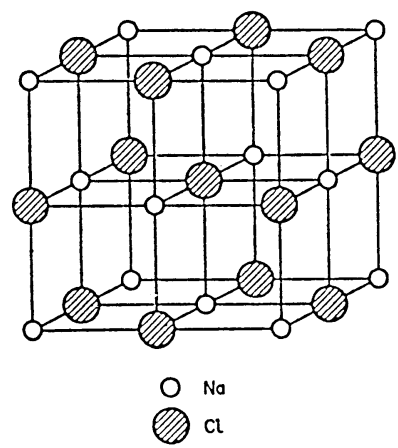

Fig.19

ンシャルエネルギーは単純に๑と@だけの引力だけです がら一 $(e)^{2} / r$ になります. 三重イオンとイオン対を比べ ていただくと絶対值は三重イオンの方が $50 \%$ 大きいわ けです.こういう単純なポテンシャルエネルギーに関し ては，3つのイオンがある場合には，マイナスがマイナ スから距離 $2 r$ 離れたところにきている方が無限大に離 れているよりも安定しているということを意味するわけ です。つまり言葉を変えますと, マイナスがマイナスを 1 つのプラスを媒介にして引っ張っているという勘定に なるわけです。

それから，例えばイオン結晶ですが (Fig. 19). この 中では, マイナスとその間にプラスが入りまして，それ でこのイオン結晶というのが安定化する。もしマイナス がマイナスだから反撥するということを強引に主張いた しますと,こういうイオン結晶というのは存在し得な い. あちろん，乙ういう電気的な力だけではなくてもっ と他の力ああるわけですが, 主に働くのはこのプラスと マイナスの間の引力がマイナスとマイナス，あるいはプ ラスとプラスの間の析力をりようがして全体を安定化し ているという，そういう話です。乙れと同じ事がラテッ クス，あるいは高分子イオンで起こっているのではなか a)
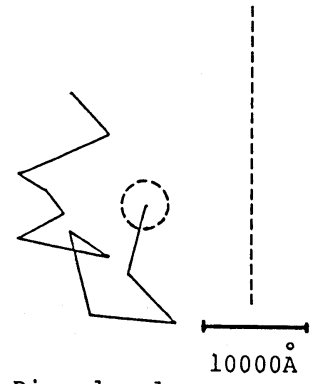

Disordered Region b)

灌 份;

这:

Ordered

Region

Fig.20 N. Ise, et al.: J. Coll. Interface Sci., 103, 292 (1985)

ろうかと．つまり，先に結果を申上げますと，ラテック スはたしかにマイナスなのですが，その間にたくさんプ ロントやカチオンがあるわけです，そうすると，さっき のイオン対あるいはイオン結晶と同じようにマイナス プラスーマイナスということになって，系全体としまし まってくる.つまり引力系になってくるわけです，

それから，同じことが分子系でもいえることで，例え ばプラスの原子核とプラスの核，乙れだけだったら分子 というのは安定ではないわけです．ところがマイナスの エレクトロンがありますために, 結局 2 つの核がエレク トロンを媒介にして安定化しているわけです.

それで，ててで 16 ミリをお目にかけます.

最初申上げましたようにてれがブラウン運動で，乙の 運動は後で申上げますがほぼ完全にアインシュタインの 法則で記述できます。乙の溶液から塩を抜きますと，同 じ濃度ですがきれいに並ぶわけです，並んでいますが, よく見ていただくと相当に乱れていることがわかりま す. 決して Fig. 15 で抄せした $\mathrm{NaCl}$ の結晶のように 非常にしっかりと固定したあのではありません．相当 に摇れるということにまずで注意いただきたい，後でど の程度摇れるかという数値を打見せします。すう少し濃
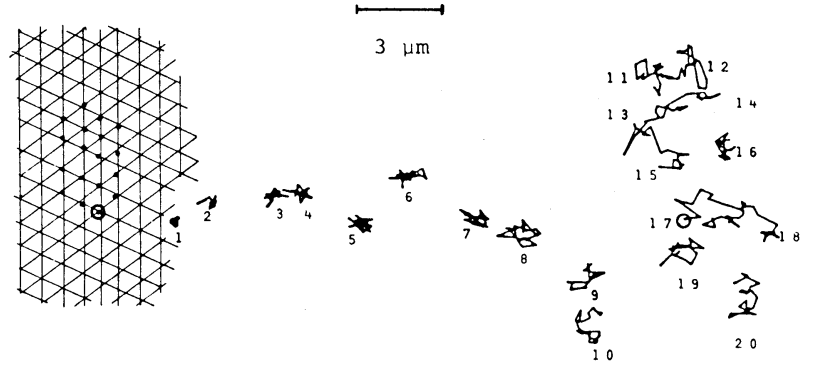

Ordered Region

Disordered

Fig.21 N. Ise, et al.: Langmuir, 1, 176(1985) 


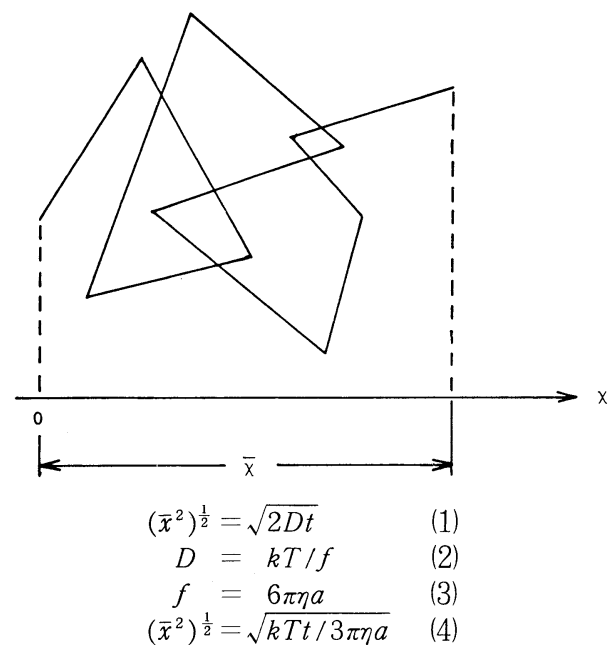

Fig. 22

Table 1 Mean Displacement of Latex Particles in Water

\begin{tabular}{cclll}
\hline & \multicolumn{2}{c}{$0.5 \mathrm{sec}$} & \multicolumn{2}{c}{$1.0 \mathrm{sec}$} \\
\cline { 2 - 5 } & $\ell(\mu \mathrm{m})$ & $\bar{\chi}(\mu \mathrm{m})$ & $\ell(\mu \mathrm{m})$ & $\bar{x}(\mu \mathrm{m})$ \\
\hline Einstein & - & 1.05 & - & 1.49 \\
Ex - 1 & 5.7 & 0.5 & 10.0 & 0.7 \\
2 & 5.3 & 0.8 & 10.0 & 1.9 \\
3 & 6.5 & 1.4 & 12.0 & 2.1 \\
4 & 5.8 & 2.4 & 11.0 & 1.0 \\
ave. & 5.8 & 1.3 & 10.8 & 1.4 \\
\hline
\end{tabular}

[latex] :0.5vol8, $25^{\circ} \mathrm{C}$, Particle diameter: $0.45 \mu \mathrm{m}$

度を下げますと，さっきのオーダーとディスオーダーが 共存しているところですね.はっきりで覧いただけると 思いますが，乙ういう写真は非常に電荷数の高いものを 作った場合だけ観測できるようです。普通ラテックスと いいますとDowあたりから売り出されているのがある のですが，それですと 1 粒子についてだいたい 1000 個 ぐらいのスルホン基ですが，我々の場合は多くした方が 引力が強くなるという, 結局, 仲立ちになるものをたく さんにしたらより強く引っ張って締まるだろうというの が予想で，その予想があたったわけです。だいたい 1 粒 子について 10000 〜 100000 個 スルホン基をむっている あのを作りますと，Fig.17のようなローカライズした オーダリングというのが写真に撮れるわけです.

つぎに，今の 16 ミリを写真に焼くわけです。そして ある粒子の中心の時間的な移動を追跡いたします。Fig. 20 がその 1 つの例ですが, 左側が 1 番最初のパートで 打見せしたランダムモーション(0.5秒)です。このスケ

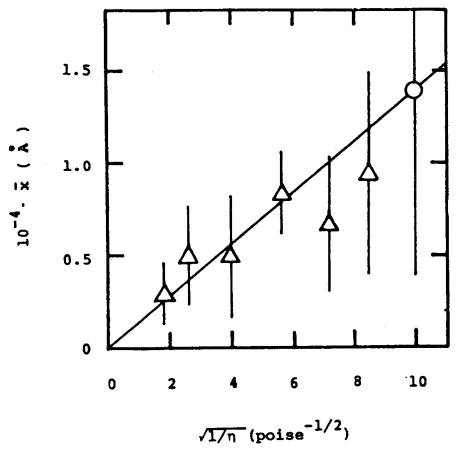

Fig.23 N. Ise et al.: J. Amer. Chem. Soc., 107, 8074 (1985)

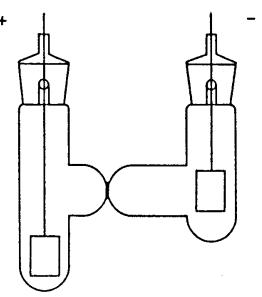

Fig.24

ールが $10000 \AA$, 右側がきれいに 6 角形に並んでいる粒 子の動きです。それで，左と右を比較していただきます とすぐにわかるように，右の動きはせいぜい粒子の直径 内に止まっている. まあ半ば振動運動, 左側の方はそう じゃなくて, 完全にアトランダムな方向に動いています. 右側が規則的でないと主張するのはかなり難かしいわけ です，確かに，分子模型程にはきれいに並んではいない わけですが, 左側の状態とは歴然と違う状態であります. それで我々は右側をオーダード状態, 左側をディスオー ダード状態とこういうわけです．Fig. 21 は，一部並ん でいて，それがランダムなあの平衡にあるという状態で す. 規則構造内部の粒子 (左側) あ相当動きますが, 乙 のスケールの中では判らない。と乙ろが右側のランダム モーションの方はかなり動きます. その中間に動きの比 較的小さな部分があります。ですから，まあ左側を固体 といい, 右側を気体というのなら, 中間は液体状態のよ うな感じになるわけです，なお，粒子の数は適当に選 んでありますので, この数の比が必らずしも実際の3つ の状態での数の比ではないわけです.

それで, 今度は自由な粒子がよ゙ういうふうに動くかと いうことです(Fig 22). 有名なアインシュタインの法 則というのがあるわけです。ある時間に $\left(\bar{x}^{2}\right)^{\frac{1}{2}}$ 動くと いう. この量がアインシュタインによって計算されてい 
Table 2 Transference Measurements of SS-36, 39, \#-1 and HPSS

\begin{tabular}{|c|c|c|c|c|c|c|c|}
\hline Latex & $\begin{array}{l}\text { Conc. } \\
\text { (voli) }\end{array}$ & $\begin{array}{c}10^{3}\left[\mathrm{SO}_{3}{ }^{-}\right] \\
(\mathrm{eg} / 1)\end{array}$ & $\begin{array}{l}10^{5} \mathrm{k} \\
(\mathrm{mho} / \mathrm{cm})\end{array}$ & f & $t_{2 p}$ & $\left(\mathrm{~cm}^{\frac{1}{2}} / \mathrm{v} \cdot \mathrm{sec}\right)$ & $\begin{array}{l}-\zeta \\
(\mathrm{mV})\end{array}$ \\
\hline sS-36 & $\begin{array}{l}1.2 \\
2.8 \\
5.5 \\
7.8\end{array}$ & $\begin{array}{l}0.39 \\
0.81 \\
1.53 \\
2.29\end{array}$ & $\begin{array}{c}1.91 \\
3.68 \\
8.03 \\
12.9\end{array}$ & $\begin{array}{l}0.13 \\
0.12 \\
0.14 \\
0.16\end{array}$ & $\begin{array}{l}0.09 \\
0.10 \\
0.13 \\
0.10\end{array}$ & $\begin{array}{l}3.4(2.6)^{* *} \\
3.9 \\
5.1 \\
3.5\end{array}$ & $\begin{array}{l}72(53)^{* *} \\
87 \\
137 \\
77\end{array}$ \\
\hline SS- 39 & $\begin{array}{l}1.5 \\
4.9 \\
7.5\end{array}$ & $\begin{array}{l}0.16 \\
0.63 \\
0.93\end{array}$ & $\begin{array}{l}0.45 \\
1.57 \\
2.71\end{array}$ & $\begin{array}{l}0.08 \\
0.07 \\
0.08\end{array}$ & $\begin{array}{l}0.05 \\
0.07 \\
0.06\end{array}$ & $\begin{array}{l}1.9(2.5) \\
2.4 \\
2.2\end{array}$ & $\begin{array}{l}36(51) \\
49 \\
43\end{array}$ \\
\hline$\#-1$ & $\begin{array}{l}0.11 \\
0.18 \\
0.23 \\
0.41\end{array}$ & $\begin{array}{r}2.8 \\
6.8 \\
8.7 \\
17.9\end{array}$ & $\begin{array}{r}4.07 \\
9.24 \\
12.5 \\
19.1\end{array}$ & $\begin{array}{l}0.04 \\
0.04 \\
0.04 \\
0.03\end{array}$ & $\begin{array}{l}0.05 \\
0.07 \\
0.10 \\
0.09\end{array}$ & $\begin{array}{l}2.8(4.1) \\
2.7 \\
3.9 \\
3.6\end{array}$ & $\begin{array}{l}57(88) \\
55 \\
83 \\
76\end{array}$ \\
\hline HPSS * & $\bar{\square}$ & $\begin{array}{l}4.88 \\
5.16 \\
9.14 \\
\end{array}$ & $\begin{array}{r}73.74 \\
79.58 \\
146.9 \\
\end{array}$ & $\begin{array}{l}0.37 \\
0.38 \\
0.38 \\
\end{array}$ & $\begin{array}{l}0.14 \\
0.14 \\
0.14 \\
\end{array}$ & $=$ & E \\
\hline
\end{tabular}

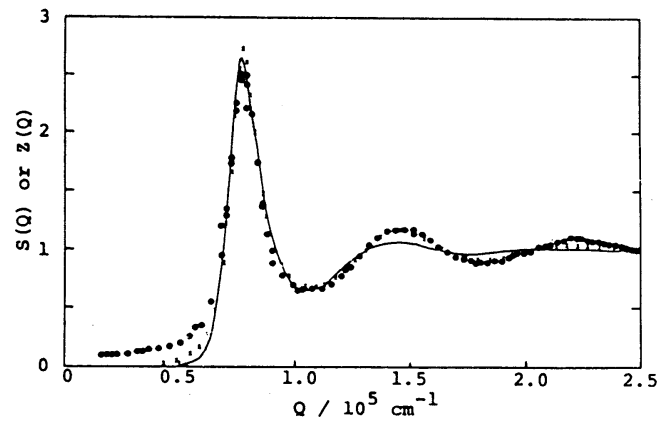

Fig. 25

るわけですがこの量が 0.5 秒， 1 秒の時にアインシュ夕 インの理論ではてうなる。せいぜい 4 つの粒子ですが平 均をとりますと 0.5 秒では $1.3 \mu \mathrm{m} .1$ 秒は $1.4 \mu \mathrm{m}$ と いうかなりアインシュタインの理論に近い值です.ただ, 何故近くなるというのが理解できなかったわけです (Table 1).乙の結果は 4 つを対象にしていますが，すっ と数を増やせという話になるだろうと思います。現在コ ンピュータで 100 個ぐらいまで増やしています.

それから，アインシュタインの理論が更によく合って いるという例 (Fig. 23) ですが.乙れは粒子の溶液の中 に庶糖を入れて粘度を上げるわけです，直線がアイン シュタインの理論值で, 三角が実測です.

で存知のようにアインシュタインの理論值というのは 相互作用をしない粒子に対して導いてあるのです．我々 の屯のは $\mathrm{SO}_{3} \mathrm{H}$ が 10000 個ぐらい付いているわけで す、だから Einstein と合う方が扔かしい，実際の有効 な電荷数を一度調べようというので, 非常にクラシカル な方法ですが，輸率実験を使いました．Fig. 24 の セル に溶液を入れまして, プラスとマイナスの勾配を印加し

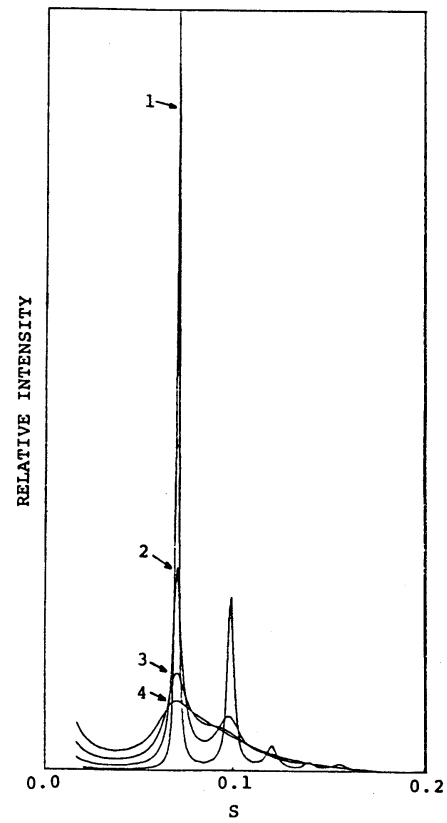

Fig.26 H. Matsuoka, et al.: J. Chem. Phys., 83, 378 (1985)

てラテックスを動かすわけです。あちろん自由なプロト ンあ同時に動きます．てうして通電後一定時間に何ファ ラディー流した時にラテックス粒子がいくら増えてきた かというのを実测するわけです. Table 2 の $f$ とうの が自由にラテックスから外へ飛び出して動き回わってい る逆イオン, 今の場合はプロトンですが, プロトンの比 率であります. SS-36では $13 \%$ SS-39 ですとわずか 8 \%ぐらいです.\#-1はものすでく電荷密度の高い屯のな のですが，そうしますと $4 \%$ 3\%。なお，参考のため に HPSS(ポリスチレンスホン酸)という可溶性高分子で 


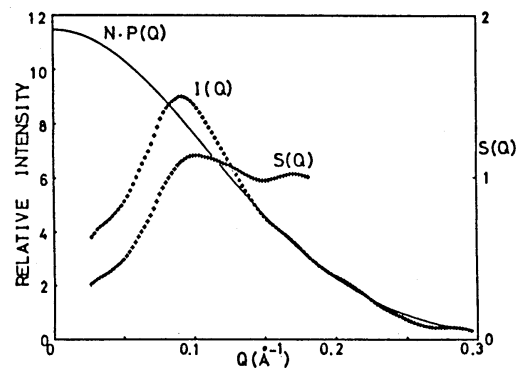

$I(Q), N \cdot P(Q), S(Q)$ for $0.05 \mathrm{~g} / \mathrm{ml} \mathrm{C} C_{12} \mathrm{H}_{25} \mathrm{NMe}_{3} \mathrm{Cl}$ in water. $N \cdot P(Q)=11.5 \exp \left(-40.7 Q^{2}\right)$

Fig.27 Y. Ishii, et al.: Ber. Bunsenges. Phys. Chem., 90, 50 (1986)

す. 同じ方法で測定したデータですが， $f$ が $40 \%$ ら゙らい です。ですから，ラテックスというのは可溶性の高分子 よりもはるかにプロトンや，逆イオンを中に引き戻して 非常に中性に近い状態で動き回わったということがいえ るかもしれません。

それから，今までは「 seeing is believing」でまた 「believing is seeing」の話に帰るわけですが, Fig. 25 は, いまのラテックスの溶液の光散乱によって測定され た構造因子 $S(Q)$ です. ラテックスは, 先ほどお見せし たように，はっきり並ぶということがわかっているわけ です，並ぶのですが実際に $S$ を測ってみますと，てうい う3つのピークしかでない．X線で高分子イオンを調べ ますと必ず 1 つかできない，ラテックスの場合はたか

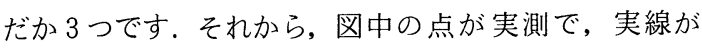
RMSA 理論 線なのですが，乙の理論は粒子間に必ず析 力しか㗢かないという仮定で, DLVOタイプのポテン シャルを仮定してでた計算の結果です．瓜力だけからの 計算值が実測値とよく合ったから，乙の系は斥力系であ

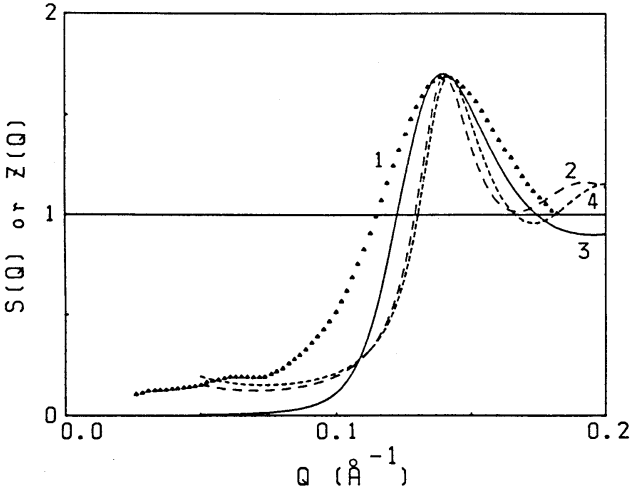

Fig.28 Y. Ishii, et al.: Ber. Bunsenges. Phys. Chem., 90, 50 (1986)

るということを明言するのですが，我々はそうは考えま せん，有名なホーゼマンのパラクリスタルの理論という のを使って，乱れを入れて $S$ を計算したのです．

てれを若干修正した理論計算が Fig. 26 です。乙れは 球が SC に詰まっているとしての計算です. 非常に乱れ が小さい場合にはカーブ 1 がでてまいります.とてろが,

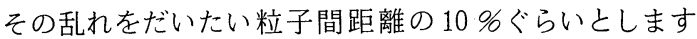
と, 乙のカーブ 4 になりまして, 高次のピークは全部消 えてしまいます。てのカーブ 4 が結局は我々が見ていま した実際のX線のカーブではなかろうかと．実際にこの 理論計算は適用いたしますと, 酵素のリゾチームですが, このホーゼマンの理論で乱れの因子をだいたい粒子間隔

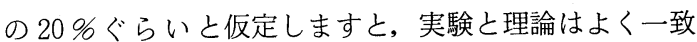
します.

最近，それから同じような実験をイオンミセルについ て試みたわけです。で存知のように, 界面活性剤分子は $\mathrm{CMC}$ 以上になりますと, 物質によりますが, 球型のミ

Table 3 DLVOの理論

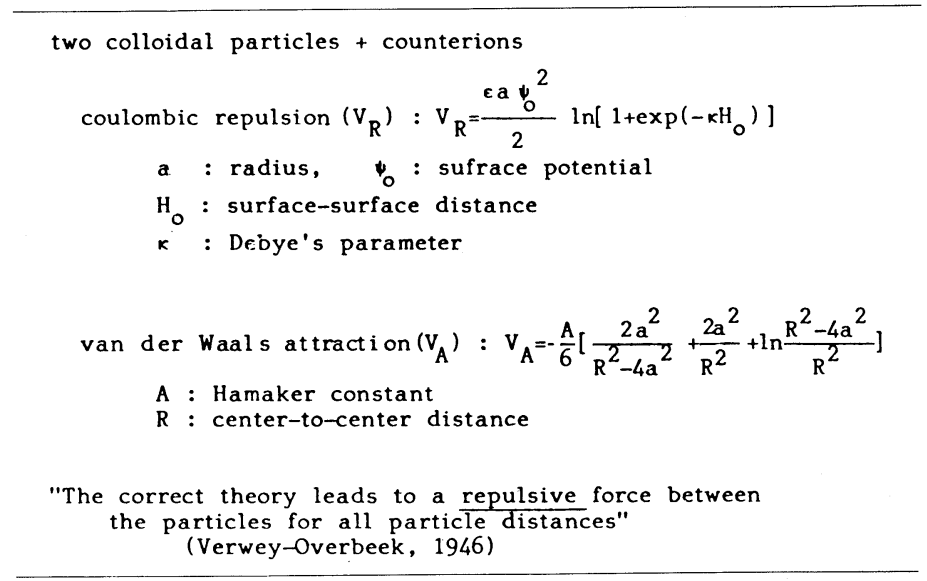


セルを作ります。この場合にはDTAC，乙れは 4 級ア ンモニウム塩型の界面活性剂ですが, 乙れを $\mathrm{CMC}$ 以上 でX線解析しますと $I(Q)$ のようにピークが観察される わけです (Fig. 27). それで, てれから Sを出して (Fig. 28, 曲線 1 ) 乙れに fittng させるように乱れの因子 $g$ と いうのを調整してやる. $g$ の因子としていたい $16 \%$ を仮 定してさらにSCの構造を仮定をいたしますと $2 つ の$ ピークをあつカーブ 2 になります (Fig. 28).

ところが，次に FCC（面心立方格子）格子を考えて, $g$ の值として $20 \%$ ぐらいを考えてやりますとカーブ 3 になります，そうすると，てれが一番実験データによく fitするわけです.

それから，BCC（体心）を考えるとカーブ4になる. ての場合むやはり第 2 ピークはでてくる，ですから， $\mathrm{BCC}, \mathrm{FCC}, \mathrm{SC}$ 仮定しましたときに，1番良かっ たのはFCCであることがわかってきました。したがっ てFCCでしかも相当乱机てるというのが, てのイオ ンミセルの話であります.

それから，斥力だけで実験と合ったという話ですが, 今のホーゼマン流の結果は Fig. 26 の実線に示してあり ます.乙の計算では引力か斥力かというのは仮定してい ません．乱れだけでてういうことがでてくるわけですか ら, RMSAの計算が実験之合ったから必ずしあ质力が 証明されたというととにはならないというととになりま す.

あと少し理論の話があります.

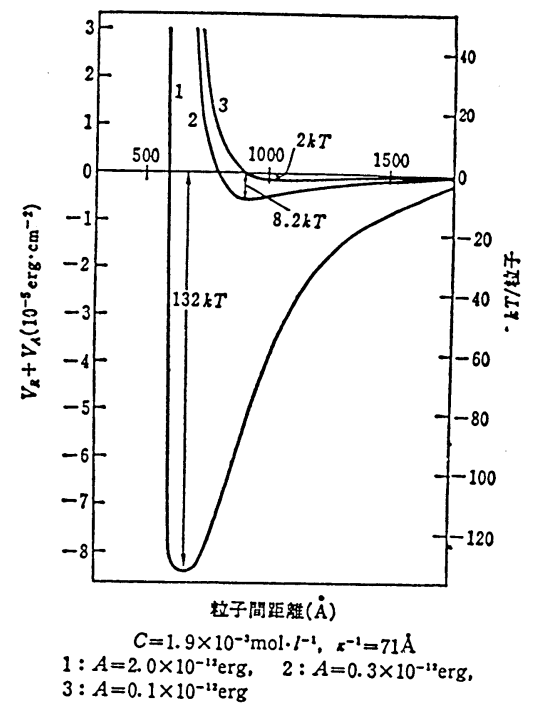

Fig. 29
要するにDLVOの理論というのがあって，それによ りますと, 2 つ球の間には電気的斥力しか働かない. 凝 縮系ですから, 斥力だけで成立っているということは起 てり得ないものですから, 当然引力を考えるわけです. 引 カとして DLVOの場合は van derWaals を考える。乙 の式の中で有名な Hameker constant (A) というの が入ってくる．従来のコロイド科学で検討してきたてと は何かといいますと, 要するにある実験方法で全体のポ テンシャルを決めておいて，そのポテンシャルに合うよ うにAをフイットさせていくわけです，相当に乱暴なて とが行われているように思います。例えば Fig. 29 はコ ロイド科学の教科書からとってきたわけですが, 粒子間 のポテンシャルカーブがどの程度 Hameker constant のえらび方によって変わるかを示しています，桁を $1 つ$ 変えただけで非常に大きく変わってくるわけです。逆に 言いますと，実験データはかなり任意に Hameker constantを選んで屯説明できることになるわけです.てれ はどうも具合悪いのじゃないかというが我々の主張で, それで, 最近, 素粒子の専門家といっしょに仕事をはじ めたわけです.物理の人ですから面白い表現をしまして, 結局ラテックス系というのはプラスチックの核を持った 原子系になるわけです，逆イオンの運動は断熱的に大き なイオンから分離するという言い方, てれは量子力学で いいますとボルン - オッペンハイマー近似です. 我々で すと，ラテックスは大きいからあまり動きませんが，逆 イオンは小さいから動きますというような表現です．1 つの本質的な点がわかってきました，DLVOの理論で は, ヘルムホルッの自由エネルギーまでの計算ですませ てあるというととです．Deriaginの論文を見ますと， ヘルホルッ・ギブス自由エネルギーというほどですから， 全然ヘルムホルツとギブスは区別していないわけです.

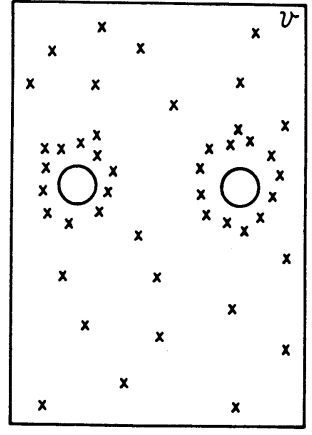

(a)

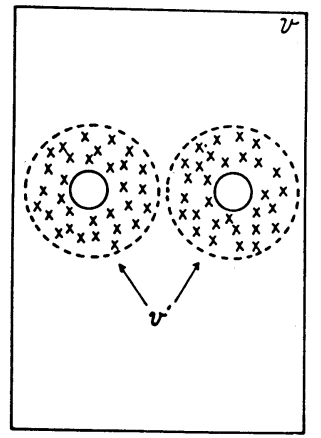

(b)
Fig.30 
詳細は省略しますが，てれを区別しますと非常に面白い ことがわかります.

結局, $\Delta G$ 之いうのは $\Delta F$ と下記の関係で結ばれる わけです. デバィ, ヒュッケルは非常に注意深くて $p d v$ 項を無視するととは, 彼らのシステムつまり小さなイオ ンの場合にはかまわないということを相当丁寧に議論し ています.そして, その議論はファウラー・グッゲン八 イムの統計力学の本にあ書いてありますが, ての議論は 他の本には書いてない，日本語ですと戸田盛和先生の液 体論には書いてあります．とにかく $p d v$ が無視できれ ば, $\Delta F$ と $\Delta G$ が等しいとしてあよろしい.とてろが,

assumption:

$$
\Delta G=\Delta F+p d v \simeq \Delta F
$$

Valid, only when volume contraction by charging - up is negligible.

(Debye-Hückel, Fowler-Guggenheim)

普通一般は, 要するに液体の場合, 電荷を持たした時の 溶液全体の体積変化が少ないものですから, $p d v$ を無 視します. 実際 Debye-Hückel はそう書いているわけ です。とてろが, どうもその仮定というのが, 高分子系 あるいは高度に荷電を持ったラテックス系では都合悪い のではないかということがわかってきたわけです．電荷 が非常に少ないコロイド系ですと. Fig. 30 a のように当 然逆イオンというのは粒子周辺にある程度集まりますが, まだ相互作用が弱いあのですから, 系の全体で逆イオン

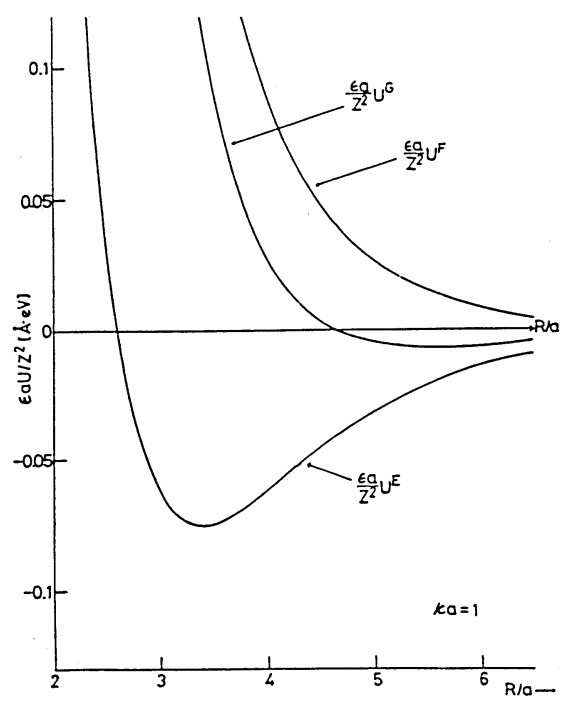

Fig.31 I. Sogami, N. Ise: J. Chem. Phys., 81, 6320 (1984)
が動き回わる.だから, 溶液の体積というのを熱力学的 なパラメータとして選ぶことは大いに意味があるわけで す.ところが, むし電荷数があのすでく高くなりますと, 逆イオンとの間に強い作用が起こります．そうすると Fig. $30 \mathrm{~b}$ のように逆イオンは引き寄せられまして, ど の程度のフラクションがわかりませんが, とにかく逆イ オンがある一定の小さな体積 $v^{\prime}$ から外へ出られないよう な状態がでてくるわけです，そうすると，電荷を与えて いく過程で $v$ からv゙へという一種の体積収縮が起こるわ けです。その効果が計算の中へ入れられますと，明瞭に 自由エネルギーのカーブが变わってくるわけです. 例 えば Fig. 31 は曽我見の理論で求めたポテンシャルカー ブですが，一番上がヘルムホルッでとめた場合のポテン シャルカーブです. 正しく DLVOの場合の曲線です. ところが先程の体積収縮を考慮にして計算すると, 乙れ が下に下がりまして二番目のようになります.比較的長 距離に非常に浅いですがちゃんとした静電気的なミニマ ムがでます.なお， $R / a$ というのは, $R$ は中心からの

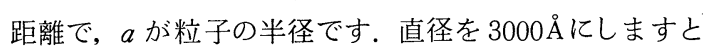
だいたいてのミニマムポイントというのは $9000 \AA ̊$ 位にな りますが, これをかなり実測に近い。一番下の曲線は系 の電気的なエネルギーだけを考えたもので，乙れで非常 に強力な引力がでてくる. てれはコロイドの歴史をで存 知の方はすぐにわかるでしょうが, Levine というのが まず最初にての計算をやりまして, コロイド粒子間に引 力があるというととを主張したら，すぐに Overbeekに よって扔かしいという指摘がされました。 Overbeek は 電気的なエネルギーだけでなくて, 電気的なエネルギー と系のエントロピー効果を考えて, 結局ての $\Delta F$ へきた わけです。な扔， $\Delta F$ だけでは足りないというのが兽我 見の指摘であるわけです。こういうことで, 面白いのは

Table 4 Simple Ions (EXAFS by Sadoc, 1980,

\begin{tabular}{|c|c|c|c|}
\hline $\begin{array}{l}\text { Conen. } \\
\text { (M) }\end{array}$ & $\mathrm{N}_{\mathrm{z}, \mathrm{B}-\mathrm{Br}}$ & 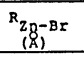 & $\begin{array}{l}20^{\circ} \\
(\&)^{2}\end{array}$ \\
\hline \multicolumn{4}{|c|}{ Sol1d Crystal } \\
\hline & 4 & 2.40 & - \\
\hline $\begin{array}{l}8.08 \\
3: 35 \\
0.09\end{array}$ & $\frac{\text { In }}{\xi .5}$ & 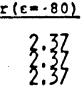 & $\begin{array}{r}4.1 \\
18.6\end{array}$ \\
\hline \multicolumn{4}{|c|}{ In Ethy1 Acetate $(\varepsilon=6)$} \\
\hline $\begin{array}{l}5: 3 \\
\text { 0:85 }\end{array}$ & $\begin{array}{l}4 \\
4 \\
4\end{array}$ & $\begin{array}{l}2.48 \\
2.30\end{array}$ & $\begin{array}{r}4.9 \\
62 \\
22\end{array}$ \\
\hline
\end{tabular}

$2 D_{\exp } \ll 2 D_{0}$ 
のポテンシャルを見ますと, 非常に電荷数の高い場合で すが, 添加塩の濃度が上りますと, このポテンシャルミ ニマムというのがだんだん下へくるわけです。下へ下が って, しかむ原点に近づきます。つまりイオン間距離が だんだん小さくなるわけです.とてろがある程度以上に なりますと，乙のミニマムポイントがまた上がりだすわ

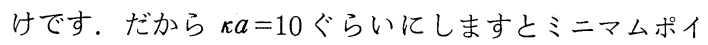
ントが消失するということです。ですから，ラテックス の場合も高分子イオンの場合もそうですが, 添加塩を入 れたらある程度距離は小さくなるわけです．添加塩を入 れて距離が小さくなるというのは実測されています.

むし DLVOの理論が正しいとしまして Hameker constant一定としますと, 添加塩を加えると, ミニマ ムポイントは単調に下がっていくわけです. ですから, DLVOが正しいとすると添加塩を入れれば入れる程, 規則構造は安定になるという実験と合わないことが起こ ります.これはそもそも蓮さんが最初に指摘したことで ఫ.

最後にこれは我々の仕事ではないのですが, フランス のサドックという人が EXAFS 実験をしまして, $\mathrm{ZnBr} 2$ の溶液中の亜鉛とブロマイドのイオンの距離を測定しま

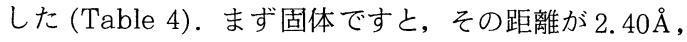
これは不思議でもなんでもないのですが, 非常に驚異な のはてれを水に溶かして $0.09 \mathrm{~mol} / 1$, これはデバイ領
域よりちょっと高いくらいの濃度ですが, その時に距離 が2. $40 \AA$ から $2.37 \AA$ になる. それからエチルアセテー ト, 乙れは誘電率 6 , その場合は $0.05 \mathrm{~mol} / \mathrm{l}$ で $2.30 \AA$ です．固体の結晶とほとんど変わらない屯のが液体状態 の中で実現している.ということはサドックのいうよう に $\mathrm{Zn}^{2}+$ と $\mathrm{Br}$-の間に固体状態と同じような長距離的な らびに短距離的な力が働いて結晶状態が再現されている ということになります. それで, 今参考のために $2 D_{0}$ と というのを計算してみたのですが, そうすると, 例えば $0.09 \mathrm{~mol} / 1$ の時に $18 \AA$, 実測距離を $3 \AA$ と見ますと $1 / 6$ になるわけです. 1 ： 2 というのが高分子イオンあるい はラテックスだったのですが, 今の場合にはもっともっ と大きくなる. 大きくなる理由は, 電荷数は確かに少な いわけですが, 粒子が小さいものですから表面のポテン シャルというものがすでく高いわけです. $10^{9} \mathrm{v} / \mathrm{cm} く ら$ いあるでしょうか？ そのために引力が非常に強くなっ ているという話です.

ということで, 高分子ラテックス, タンパク質, それ から高分子イオンに限らず電荷をもっている粒子ですと すべて, かなりローカルにオーダーを作り, しかあかな り乱れの大きいオーダーを形成していると考えるとい ろいろな現象が説明できるのではなかろうかということ でございます。どう屯ありがとうございました。

\section{北米膜学会ニュースレター創刊}

本年 1 月から発足した北米膜学会, North American Membrane Society (会長, Prof. Elias Klein,Univ. of Louisville, KY) がこのたびそのニュースレター “Membrane Quarterly”（25ページ）を発行した。そ の巻頭で Klein 会長は現在我々が準備中の1987年国際膜 会議 (ICOM' 87) のことにふれ, 北米からの参加者のた めに charter flightを計画していること, また次回は米 国で行いたいとの希望を述べている.

北米膜学会は第 1 回の講習会として“Membrane Materials Science Workshop” 1986年10月6ー7日, Austin, TXで行い, 講師にはW.J. Koros, H. B. Hopfenberg, S.Z. Jakabhozy, C. G. M. Quah, L. Zemanの諸氏を予定している. 連絡先はProf. D. R. Lloyd (Dept. of Chem. Engineering, The Uni- versity of Texas at Austin, Austin, TX 78712, U.S.A.) である.

北米膜学会は第 1 回年会を 1987 年 6 月 $3-5$ 日, Cincinnati, $\mathrm{OH}$ で行う予定であり, それに先立って 6 月 $1-2$ 日に第2 回講習会を同じ場所で行うことにしてい る.

このニュースレターには技術情報, 特許などに関する 記事屯あり, また我々の “膜”第 11 巻 1 号および 2 号 の主要論文の著者名と論文題目屯掲載されている.

北米膜学会は年会費 \$35 であり, 会員は Journal of Membrane Science を定価の半額 (\$190)で購読するて とが出来る. 入会申込書の必要な方は日本膜学事務局ま で申出て下さい. 